\title{
Az egri Főegyházmegyei Könyvtár egyházjogi állományának vizsgálata a könyvtár alapításától 1899-ig
}

Jelen tanulmányban az egri Főegyházmegyei Könyvtár kánonjogi állományát vizsgáltam meg a gyüjteményben megjelenő művek kiadási ideje, helye, nyelve és tematikája fényében. A könyvtár alapításától 1899-ig terjedő időszak tekintetében megfigyelhetjük, hogy a kánonjogi kutatásokat szolgáló források föleg francia nyelvterületről érkeznek, azonban a különböző szisztematikus kérdéseket tárgyaló munkák jelentős része német eredetü. Számos tematikus egységet elkülönítve megállapítható, hogy az egyházjogi gyűjtemény főként tanítási, másodsorban pedig a szentszéki jogszolgáltatás működéshez szükséges eljárásjogi célokat szolgálta.

A történelemtudomány több határterületével együtt számos alkalommal foglalkozott már a 18. századi magyar bibliotéka-alapítások történetével, így köztük az egri Eszterházy Károly püspök által 1793-ban megalapított egri Főegyházmegyei Könyvtár historiográfiáját is már többen tették kutatásaik tárgyává. ${ }^{1}$ Eszterházy könyvtára természetesen nem választható külön az egyetemalapítási kísérletétől, hiszen a nevezett gyüjtemény jellegéből adódóan is szolgálni hivatott a felsőfokú oktatást.

E tanulmányban elsődlegesen a nevezett püspöki könyvtár egy többé-kevésbé jól elkülöníthető állományát teszem vizsgálatom tárgyává. Jelen írás az egri líceumi könyvgyüjtemény egyházjoggal, kánonjoggal foglalkozó szakirodalmára igyekszik fókuszálni figyelmét, és be kívánja mutatni, hogy milyen kánonjogi - az egyház jogrendjével foglalkozó - munkák kerültek felvételre benne.

Mivel Eszterházy könyvtára igen gazdag állománnyal rendelkezett, ezért elkerülhetetlen, hogy a jelen tanulmányban tett kijelentések egy része igaz legyen a vizsgált kor kánonjog-irodalmára tágabb értelemben is, hiszen ahogyan az olvasó látni fogja, az egri könyvtár magába foglalta a vizsgált időszak alatt az egyébként is megjelent egyházjogi munkák jelentős részét.

1 Vö. Antalóczi Lajos: Az egri Főegyházmegyei Könyvtár története 1793-1989. Eger 1989.; Löffler Erzsébet: Az Egri Főegyházmegyei Könyvtár. In: Az egri Domus Universitatis és Líceum. Oktatás, tudomány, művészet. Szerk. Petercsák Tivadar. Eger 2013. 173-242. 


\section{Előzetes megjegyzések}

A kutatás során alapvető forrásként Michalek Manó (Emánuel) (1838-1915) egri kanonok, majd pedig 1888-tól az egri Érseki Lyceumi Könyvtár vezetőjének grandiózus gyűjtőmunkája szolgált. Michalek elsőként 1893-ban adta ki „Az Egri Érsekmegyei Könyvtár szakszerű czímjegyzéke" c. kétkötetes állományjegyzékét, melyben tematikus egységekbe rendezve írta le a kutatott könyvtár munkáit 1893 -ig. ${ }^{2}$ A jelen tanulmány tárgyául szolgáló egyházjogi művek az első kötetben kerültek feltüntetésre, a „Jogtudományok” tárgyegységén belül „Egyházi jog, zsinati végzések, bullák, decreták” megjelöléssel. ${ }^{3}$ Ezt követően még két „pótlékfüzetet” jelentetett meg az említett szerző 1894-ben ${ }^{4}$ és 1900-ban ${ }^{5}$. Mindkét munkában a fentiek szerint kerültek közreadásra a kánonjogi témájú könyvgyarapodások. ${ }^{6}$

Azonban a címjegyzékek más fejezeteiben (pl. jogtörténet) is található elvétve egyházjogi tematikájú munka, éppen ezért ezek áttekintése elengedhetetlen. Ugyanakkor jelen kutatás figyelembe vette az állam és egyházak jogi viszonyát bemutató értekezések mellett nem csupán a katolikus egyház, hanem a más felekezetek, és vallások joganyagát tematizáló munkákat is.

A kutatás során a több kötetből álló művek nem kerültek az egyes részadatok szempontjából szétbontásra, így egy munkaként nyertek feldolgozást. A kutatás eredményei a tanulmány grafikus szemléltetéseiben százalékos arányosításban kerülnek feltüntetésre. A könyvészetről szóló szakirodalom jártas olvasója minden bizonnyal könnyedén felfedezi majd, hogy jelen sorok szerzője témájával sokkal inkább a kánonjog, mintsem a könyvtártudomány szemszögéből kíván foglalkozni.

\section{A Főegyházmegyei Könyvtár kánonjogi állománya}

A könyvtár kánonjogi állományának minél teljesebb körű feltérképezéséhez négy szempont szerint került rendezésre az az 1541 munkát kitevő szakirodalom-gyűjtemény,

2 Michalek Manó: Az Egri Érsekmegyei Könyvtár szakszerű czím-jegyzéke I-II. Eger 1893.

3 Uo. 554-603.

4 Michalek Manó: Az Egri Érsekmegyei Könyvtár szakszerủ czím-jegyzéke. I. pótlék-füzet. (18911893. évi gyarapodás). Eger 1894.

5 Michalek Manó: Az Egri Érsekmegyei Könyvtár szakszerű czím-jegyzéke. II. pótlék-füzet. (18941899. évi gyarapodás) Eger 1900.

6 Vö. Michalek Manó: Az Egri Érsekmegyei Könyvtár szakszerű czím-jegyzéke. I. pótlék-füzet. (1891-1893. évi gyarapodás). Eger 1894. 59-64.; Michalek Manó: Az Egri Érsekmegyei Könyvtár szakszerű czím-jegyzéke. II. pótlék-füzet. (1894-1899. évi gyarapodás), Eger 1900. 38-39. 
mely az egyházi jog és határterületeinek témaköréhez sorolható. Amennyiben összevetjük ezt a könyvtár 1899. évi teljes állományával, mely Mihalek számításai szerint 46863 írást tesz $\mathrm{ki}^{7}$, úgy elmondhatjuk, hogy a kánonjogi állomány a teljes gyüjtemény 3,28 \%-át képezte. Természetesen a jelenleg összegyüjtött 1541-es szám sem tekinthető végleges és teljesen pontos eredménynek, hiszen a tematika szerinti besorolás rámutat arra, hogy több esetben fedezhető fel olyan tartalmi átfedés (pl. zsinattörténeti munkák esetében), melyek miatt joggal tarthat számot egy mủ kánonjogi relevanciára is. Ezenkívül a vizsgált időszakban maga a kánonjog-tudomány(i) is még több ponton más jelleggel bírt, hiszen, a ma ismert (első [1917] és második [1983] kodifikáció utáni) formáját csak a 20. században nyerhette el. ${ }^{8}$

„Eszterházy könyvtára - noha kódexek, ősnyomtatványok és egyéb könyvritkaságok is akadtak benne - elsősorban a felsőoktatást kívánta szolgálni, a négy fakultást arányosan képviselve, vagyis a püspök olyan alapkönyvtárat kívánt létrehozni, ahol mindenki megtalálja a számára szükséges korszerű irodalmat.” ${ }^{9}$ E gondolat alapján az egyházjog is megjelent Eszterházy szempontjai között, melyet a könyvgyűjtésben résztvevő munkatársak számára küldött: „A jogtudomány kútforrásai, azaz: közügyek tárgyalásai, fejedelmi összejövetelek jegyzőkönyvei, békekötések, államszerződvények, ország-gyülési naplók, s az egyházi és polgári jogot előadó, fejtegető könyvek.” ${ }^{10}$ A kánonjogi egység alapvetően egyetemi képzést szolgáló karaktere jelen kutatás során is igazolást nyert.

Jelen tanulmány követi a vizsgálati szempontok négyes felosztását. Elsőként ezért a nevezett gyűjtemény keletkezési idejét szükséges közelebbi vizsgálat tárgyává tenni. Ezt követően a corpus nyelv szerinti megoszlása, majd pedig az ehhez néhol szorosan kötődő kiadás helye kerül feltérképezésre. Jelen tanulmány végén teszek arra kísérletet, hogy az így körvonalazott gyüjtemény tematikus egységei is felvázolásra kerüljenek, mely minden előbbi közül a legösszetettebb feladat.

7 Vö. Michalek Manó: Az Egri Érsekmegyei Könyvtár szakszerű czím-jegyzéke I., Eger 1893. IX.; Michalek Manó: Az Egri Érsekmegyei Könyvtár szakszerü czím-jegyzéke. I. pótlék-füzet. (18911893. évi gyarapodás), Eger 1894. III.; Michalek Manó: Az Egri Érsekmegyei Könyvtár szakszerű czím-jegyzéke. II. pótlék-füzet. (1894-1899. évi gyarapodás), Eger 1900. III.

8 Vö. Fantappiè, Carlo: Dal paradigma canonistico classico al paradigma codificatorio., in: Ius Ecclesiae 29 (2017), 39-50

9 Löfler E.: Az Egri Főegyházmegyei Könyvtár i. m. 184.

10 Uo. 184. 


\section{A könyvtár kánonjogi állományának kor szerinti megoszlása}

A több mint 400 éves távlatban vizsgált korszerinti megoszlás viszonylag egységes képet rajzol az egri Főegyházmegyei Könyvtár kánonjogi állományát tekintve.

Két darab 1500 előtti egyházjogi tematikájú ősnyomtatványt őriznek a bibliotéka állományában. Ezeken kívül további 9 munka származik az 1500 és 1540 közé eső időszakból. E munkák többsége Párizsban, Lyonban vagy esetleg Bázelben kiadott klasszikus kánonjogi gyüjtemény, mint például a Gratianus „Concordantia discordantium canonum" műve, mely több kiadásban is $(1493,1584,1861)$ fellelhető Egerben, vagy a IX. Gergely pápa által promulgált „Liber extra”-ként elterjedt joggyüjtemény $(1505,1510,1511,1553,1573,1601,1773)$ szintén becses darabja a könyvtárnak. ${ }^{11}$ Természetesen a jelentősebb kollekciók, így a Corpus Iuris Canonici több kiadásban is megtalálható az állományban.

A klasszikus kánonjogi irodalom egyébként gazdag dekretalista munkái csekély mértékben jelennek meg a Főegyházmegyei Könyvtárban, azonban a fent már említett forrásokon kívül a „Liber sextus”-ként ismert gyüjtemény, vagy a Quinque compilationes antiquae egyes példányai részét képezik a gyüjteménynek.

A vizsgált szegmens állománya leginkább az 1700-as évek elejétől kezd gyarapodni, mely folytatódik egészen a 18. század végéig. Hasonló élénk egyházjogi kutatómunkának lehetünk tanúi a 19. század közepétől. Egyértelmű és jól elkülöníthető okait nem lehet feltárni annak, miért ezekben az években került több egyházjogi munka kiadásra. Mindkét esetben jelentékeny szerepet játszhatott az állam és egyház viszonyát vizsgáló számos kérdésfelvetés. Ugyancsak meghatározta a 19. századi gyarapodást a francia Jacques-Paul Migne grandiózus kiadói tevékenysége, mely esetünkben a kánoni jog forrásaként szolgáló fóként a pápai leveleket, dekrétumokat és különböző kiváltsággyűjteményeket, és egyetemes zsinati szövegeket jelenti.

További kutatásokra tarthat számot annak a kérdésnek a tisztázása, hogy a könyvtári állomány mennyire tudta követni a 20. század elején napvilágot látott új egyházjogi munkák megjelenését, melyeket kezdetben fóként az első kánonjogi kodifikáció (1917) inspirált.

11 Vö. Erdő Péter: Az egyházjog forrásai. Bp. 1998.; A nevezett jelentősebb gyűjtemények kutatásának jelenlegi állásáról lásd: Anne J[osephine] Duggan: Current Research on decretals between Gratian's Decretum and the Liber Extra. Ephemerides juris canonici 57. (2017) 245-275. 


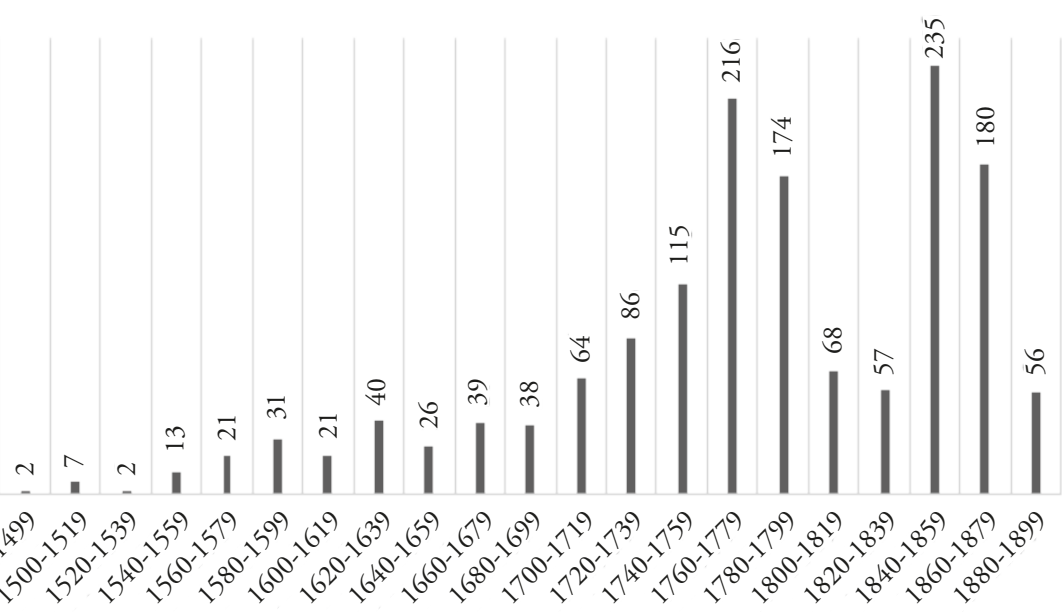

1. ábra: A könyvtár egyházjogi állományának kor szerinti megoszlása darabszámban megadva

\section{A könyvtár kánonjogi állományának nyelvi megoszlása}

A legkisebb meglepetéssel talán az Eszterházy bibliotéka egyházjogi állományának nyelvi megoszlása szolgál. A latin nyelv II. Vatikáni Zsinatig domináns jellege a katolikus teológián belül, különös tekintettel pedig az egyházjog tudományára, vitán felül álló. Az egyházjog talán annyiban volt a jelen kutatás időintervallumán belül (illetve van tulajdonképpen mind a mai napig) speciálisabb helyzetben, hogy alapvető szöveges forrásai (egyházi törvények - kánonok, pápai rendelkezések, zsinati gyűjtemények) szinte kivétel nélkül latin nyelven íródtak, mely tovább erősíti annak befolyását a tudomány egész területére nézve. Az egyházjogi irodalomban az 1917es Codex Iuris Canonici megjelenése után kezd erőteljesebben megjelenni a nemzeti nyelv, mely az Eszterházy könyvtár 1899-ig vizsgált állománya szempontjából is előrevetíti a vizsgálat eredményét.

A kánonjogi gyüjtemény 64\%-a latinul íródott. Különösen jelentősek itt az ún. primer források, melyek a tudományterület esetében a pápai dokumentumok, egyetemes és részleges zsinati rendelkezések és egyéb joggyüjtemények.

Ezt követi a közel azonos arányban fellelhető német és magyar nyelv. Mindkét esetben alapvetően igaz, hogy a nemzeti nyelven íródó művek túlnyomó többsége a 19. századra, annak is inkább a második felére tehető. Mivel a németajkú 
kanonisztika már a 18. illetve 19. században igen gazdag volt a népnyelvü tudományos munkákban (lásd: Ferdinand Walter, George Phillips munkái, melyek szintén megtalálhatóak a könyvtár anyagában), ezért egyértelmű a nyelvi túlsúly ezen a téren. Ahogyan az 1781-1784 közötti szisztematikus külföldi könyvtári gyűjtőmunkálatok is mutatják, németajkú tudományos központokban (lásd: pl. Tübingen, Bécs) számos munkát vásároltak, ezeken kívül azonban a német nyelv szempontjából jelentékeny szerepet játszott még Köln, Augsburg, Frankfurt és Regensburg is. A német kánonjogi kultúra dominanciáját tovább árnyalja a jelen tanulmány további részében bemutatott kiadások helyének megoszlása.

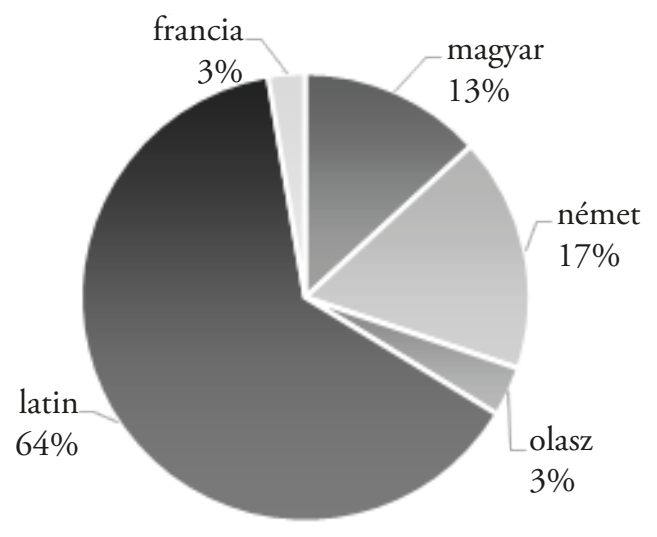

2. ábra: A könyvtár egyházjogi állományának nyelvi megoszlása

A 13\%-ot kitevő magyar állomány jelentős hányada a 19. század második felében keletkezett, amikor is egyes szerzők (pl: Fejér György ${ }^{12}$, Szeredy József ${ }^{13}$, Udvardy Ignác $^{14}$ Porubszky József ${ }^{15}$, Konek Sándor ${ }^{16}$, Oltványi Pál ${ }^{17}$, Haudek Ágoston ${ }^{18}$, Kazaly Imre ${ }^{19}$ ) elkezdték elkészíteni áttekintő jellegű, sokszor tankönyvként használható kánonjogi traktátusaikat. Ezek mind megtalálhatóak az egri könyvtár állományában.

Végül pedig mindezeken kívül még 3-3\%-ban olasz és francia szakirodalom is fellelhető.

12 Fejér György: Egyházi fejtegetések mostani szükségekre nézve. Pest 1841.

13 Szeredy József: Egyházjog. Pécs 1874.

14 Udvardy Ignác: Róm. ker. kat. egyh. jogtan. 1-2. köt. Buda 1843.

15 Porubszky József: Katholikus egyházjogtan Eger 1863.

16 Konek Sándor: Egyházjogtan kézikönyve. Pest 1863.

17 Oltványi Pál: Vegyesházasságok és az új polgári törvénykönyv. Temesvár 1854.

18 Haudek Ágoston: Egyházi-társadalmi alapjogtan müvelt kath. számára. Győr 1884.

19 Kazaly Imre: A kath. egyházjogtan kézikönyve. Vácz 1877. 


\section{A könyvtár kánonjogi állományának megoszlása a kiadás helye tekintetében}

Ameddig az egyes művek nyelvi megoszlás nem mutatja meg pontosan, hogy a könyvtár egyházjogi állománya esetében mely régiók és országok dominálnak, addig erről sokkal pontosabb képet nyújt az, ha - amennyiben feltalálható - a munkák kiadásának helyét vesszük górcső alá.

A kánonjogi corpus keletkezési helyeként alapvetően négy nemzeti terület határozható meg, melyek némelyike területileg aligha volt egységesnek mondható a 400 évet felölelő kutatási intervallum során, mégis a jelen vizsgálódás szempontjából nyelvi és tudománytörténeti aspektusból ez mégis figyelmen kívül hagyható.

Az egyházjogi állomány legjelentősebb része francia területről származott $(32 \%$, közel 550 munka). Ennek túlnyomó többségét (500 könyv) - már csak Jacques-Paul Migne tevékenysége okán is - Párizs adta. Így a francia területekről érkező gyüjtemény igen jelentékeny részét képezték a pápai döntvénytárak és levélgyüjtemények. Ezzel szemben azonban az egyedi kánonjogi kérdésekkel foglalkozó egyéni munkák sokkal ritkábban származtak a nevezett országból.

A kánonjogi gyüjtőkör második legjelentősebb egységének a németajkú területek bizonyultak. Az állomány 28\%-át (több mint 450 könyv) kitevő nyelvi közeg azonban a kiadás helyét tekintve már közel sem olyan egységes, mint Franciaország esetében. Több mint 50 helyről érkeztek kiadványok a vizsgált régióból. A legjelentősebb kiadási helyek gyanánt Bécs, Augsburg, Köln, Frankfurt és Regensburg jelölhető meg. Ezek közül is kiemelkedik az osztrák főváros, mely már csak a Habsburg Birodalom miatt, illetve a város közelsége okán is könnyen elérhető volt a könyvbeszerzés számára.

19\%-ot (közel 320 könyv) tesznek ki az itáliai területekről érkező kánonjogi traktátusok. Ebben az esetben - a német mintához hasonlóan - noha szintén számos város (több mint 30) lelhető fel kiadási hely gyanánt, mégis a francia példát követve a számottevő többség Velencére és Rómára korlátozódik. Utóbbi ténye aligha is szorul külön magyarázatra a kánonjogi állomány vizsgálata során, továbbá Róma Velence mellett gyakran tűnt fel a 18. század végi könyvvásárlási számlákon is. ${ }^{20}$

Bár csak a kánonjogi állomány 13\%-a készült magyar nyelven, azonban a területi megoszlása tovább árnyalja a hazai egyházjogi kultúra könyvtári megjelenését, hiszen a Trianon előtti magyar területekről a munkák 18\%-a (kicsivel több mint 300 tétel) származik. Hasonlóan az olasz példához itt is számos helyről (több mint 30) érkeztek szakkönyvek, azonban a magyar állomány jelentős részét (125)

20 Löffler E.: Az Egri Főegyházmegyei Könyvtár i. m. 185. 
a fővárosban (Pest, Buda, vagy később Budapest megjelöléssel) adták ki. Ezt követi még Eger, Nagyszombat, Pozsony és Esztergom, mint a magyar területek legjelentősebb kiadási helyei az egyházjogi állomány tekintetében. ${ }^{21}$

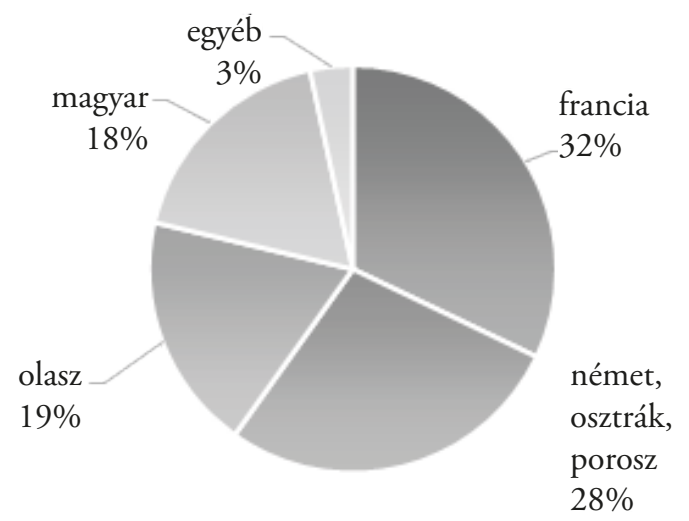

3. ábra: A könyvtár egyházjogi állományának kiadás helye szerinti megoszlása

A corpus 3 \%-át alkotják a más területekről (jelenlegi cseh, lengyel, belga, holland, angol) származó művek.

\section{A kánonjogi állomány tematikus megoszlása}

A fentiekkel ellentétben a vizsgált gyüjtemény tematikus rendezése és értékelése igen jelentős kihívás elé állíthatja a jogtörténészeket, hiszen aligha lehetséges sokszor pontos határvonalakat húzni egymáshoz szorosan kapcsolódó jogterületi egységek közé, másrészt pedig közvetlenül nem is célszerủ használni a mai tematikus fogalmaink szerinti kánonjogi felosztásokat, hiszen azok csak közvetett módon feleltethetők meg egy négy évszázadot felölelő könyvállomány besorolásának. E kutatás végzője 14 különböző kategóriát állapított meg, melyekben több esetben további alegységek állapíthatók meg.

21 A közelmúltban jelent meg az a bibliográfiai számbavétel, amely az egri Püspöki, majdan Érseki Líceumi Nyomda kiadványpalettáját ismerteti a teljesség igényével (valamennyi korabeli egri jogi kiadvány könyvészeti- és lelőhelyadataival): Mizera Tamás - Nagy Andor - Verók Attila: A könyvkiadó egri Líceum. Történet és kiadványjegyzék I-II. (1755-1949). (Kulturális Örökség 7-8.) Budapest-Eger 2017. A helyi officina nyomdai működésének átfogó bemutatásához lásd: Nagy Andor: A könyvkiadó egri Líceum tevékenysége a statisztikai adatok tükrében (1755-1949). In: Mizera T. - Nagy A. - Verók A.: A könyvkiadó i. m. 37-54. 


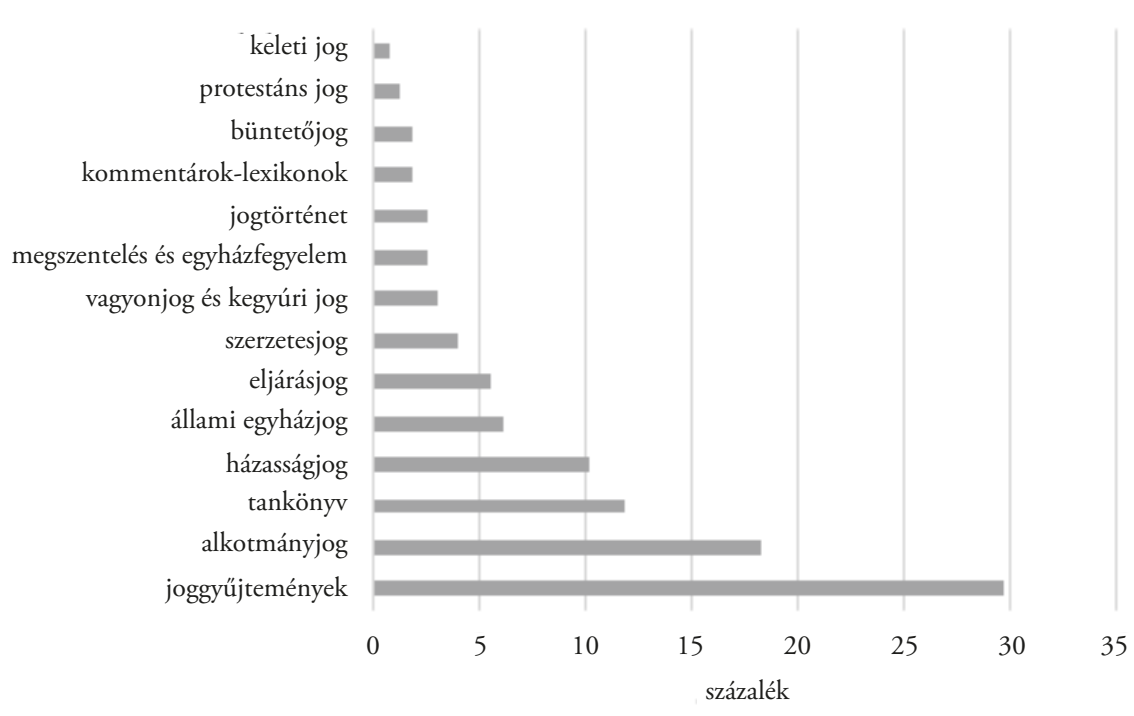

\section{4. ábra: A könyvtár egyházjogi állományának tematikus megoszlása}

A kánonjogi corpus legjelentősebb egységét (29\%, közel 500 mü) a különböző joggyüjtemények teszik ki. Mivel 1917 előtt nem létezett olyan többé-kevésbé egységes jogforrás, mint a jelenleg is használt Codex Iuris Canonici² ${ }^{22}$, ezért különösen is fontos szerepet kaptak a különböző egyházi hierarchikus szintek által kiadott, egyedi esetre szóló rendelkezéseket összegyüjtő forrásmunkák. Ennek fényében négy ilyen altípust különíthetünk el a vizsgált egri könyvtár esetében is. A számszerủleg legjelentősebbként a különböző részleges egyházmegyei vagy nemzeti zsinatok rendelkezésgyűjteményei tarthatók számon. Az alkotmányjogi állomány 40\%-át kitevő ilyen zsinati források a teljesség igénye nélkül felölelik a Trienti Zsinattól megtartott magyar és további Kelet-Közép-európai részleges szinódusokon született rendelkezéseket. A nevezett alkotmányjogi állományban ugyancsak megtalálhatók a már többször időzett Migne-féle kiadásban a különböző pápai levelek és dekrétumok, melyek annak kb. negyedét (26\%-át) teszik ki. Ezt követik a különböző egyetemes zsinati rendelkezéseket kiadó művek (18\%). Végezetül egy további alkategória is körvonalazható, melybe az előbbiekbe nem besorolható - legtöbbször klasszikus kánonjogi joggyüjtemények (vö. Decretum Gratiani, Liber extra, Liber sextus,

22 CIC (1917): Codex Iuris Canonici, Benedicti PP XV auctoritate promulgatus, (1917. május 27.) és Codex Iuris Canonici, auctoritate Ioannis Paulis PP. II promulgatus (1983. január 25.). Utóbbi magyarul: Erdö Péter (szerk., ford., magy.): Codex Iurius Canonici. Az Egyházi Törvénykönyv. Bp. 2015. 
Quinque compilationes antiquae) - egyéb jogforrások kerültek. Összhangban a kodifikációs kor előtti kánonjog sajátosságával a könyvtár tematikus egyházjogi állományának legjelentősebb részét maguk a törvénygyűjtemények alkották.

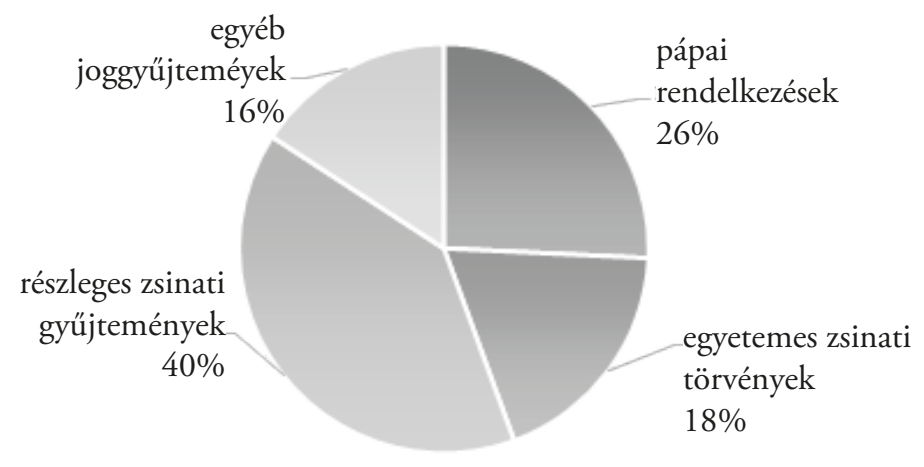

5. ábra: A kánonjogi állomány joggyüjteményeinek további megoszlása

A kánonjogi corpus második legjelentősebb tematikai egységeként az alkotmányjogi is további részekre bontható: egyrészt elkülönítésre kerültek a katolikus egyházi szervezet különböző szintjeivel foglalkozó tanulmányok (pápaság Szentszék, megyéspüspökök és egyházmegyei szint, alsópapság - plébániák szintje), illetve azon általánosan alkotmányjogi jellegü értekezések, melyek előbbi három egységbe nem sorolhatók.

A vizsgált korszak egyházjogi szerzői igen nagy figyelmet szenteltek a pápaság, a római pápa, illetve ezzel összefüggően a Szentszék és annak egyes egységeinek közelebbi tanulmányozására. Az alkotmányjogi állomány több mint harmadát (34\%) e művek gyüjteménye teszi $\mathrm{ki}^{23}$, melyek igyekeztek hol a Vatikán területe kapcsán megfogalmazott kontroverziákra, máskor pedig az I. Vatikáni Zsinat kapcsán a pápai infallibilitás dogmájára, vagy a primátus kérdésére kánonjogi módszerrel reagálni. Hasonlóan komoly érdeklődéssel fordult nem csak a kánonjogi irodalom, de a könyvtári beszerzés a munkák azon második csoportja felé, melyek a részegyházak (legyen e fogalom bármennyire is anakronisztikus a vizsgált történeti korban) vezetésének kánonjogi tanulmányozására igyekeztek koncentrálni. Ide kerültek besorolásra a megyéspüspökkel, tevékenységével (pl. vizitációk), egyházmegyéjével, annak különböző magasrangú hivatalaival (pl. káptalani testület) foglalkozó traktátusok. ${ }^{24}$

23 Pl. Wilhelm Barclaii J. C.: Abhandlung von der Macht des Papstes in zeitlichen Dingen, H.n. 1768.

24 Pl. H. n.: Wozu bedarf die katholische Kirche auch fernerhin der Bischöfe?. Augsburg 1805. 
Hasonlóan az előbbi egységhez, ez is az alkotmányjogi állomány harmadát alkotja (31\%). További kutatásokra sarkallhat a tény, hogy az alsópapság helyzetével, a plébániák jogi körülményeivel meglehetősen ritkán foglalkozik a könyvtár alkotmányjogi állománya $(9 \%) .{ }^{25}$ Végezetül pedig megtalálható az alkotmányjogi munkáknak egy jelentősebb, 26\%-ot kitevő egysége, melyek általánosságban a katolikus egyház jogi státuszával, immunitásával, hatalmával és annak gyakorlásával - sokszor az apologetikus jelleget sem mellőzve - foglalkoztak. ${ }^{26}$

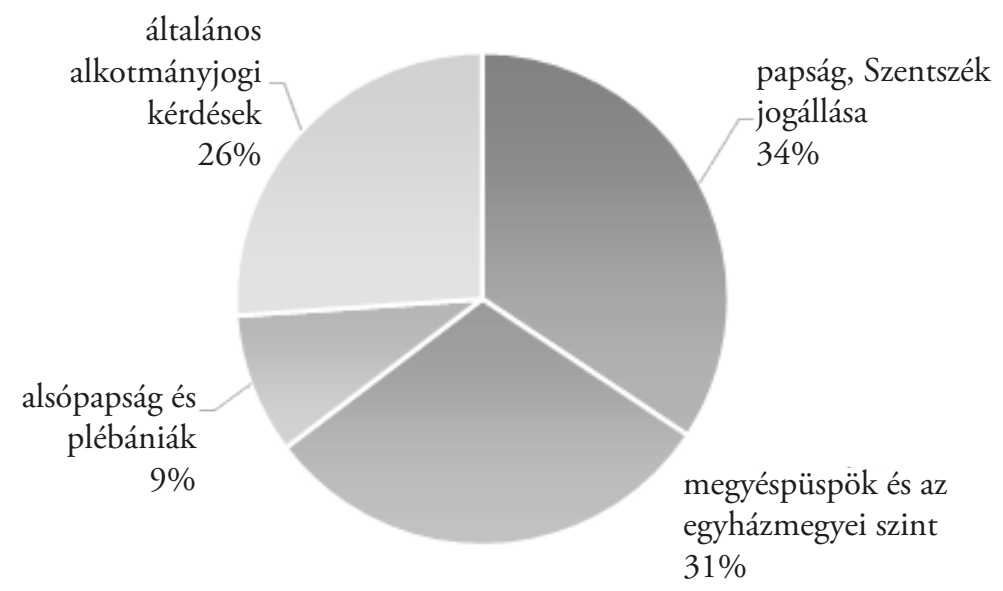

\section{6. ábra: A kánonjogi állomány alkotmányjogi részének további megoszlása}

Ha figyelembe vesszük a könyvtáralapítás és az egyetemalapítási kísérlet szoros összefonódását, illetve a tényt, hogy a 17. századtól intézményes formában is folyt már papnevelés az Egri Egyházmegyében, nem meglepő, hogy a vizsgált könyvtár állományának harmadik legjelentősebb részét azon kánonjogi kézikönyvek és tankönyvek adják ${ }^{27}$, melyek a szemináriumi és később joglíceumi egyházjogi képzés során elengedhetetlenek voltak. 12\%-kal, közel 200 művel, a (fóként latin, azonban elvétve később német és magyar) tankönyvállomány ugyancsak jelentős szerepet játszott a kodifikáció előtti korban egy-egy kánonjogi kérdés szisztematikus áttekintésében, melyekhez az esetlegesen szükséges jogforrások elszórva voltak csak fellelhetők.

A könyvtár állományában ezután olyan jelentős tematikus csoportok következnek, mint a mindig is nagy tudományos érdeklődésre számot tartó házasságjog (10\%, több mint 160 mü) valamint állam és egyház viszonyát tárgyaló állami

25 Pl. Barbosa Augustin: De Officis et Potestate Parochi. Venetiis 1635.

26 Pl. Josephus Porubszky: De Independentia potestatis Ecclesiastiae ab Imperio Civili. Agriae 1841.

27 Pl. Carlo Sebastiano Berardi: Institutiones Juris Ecclesiastici. Venetiis 1777. 
egyházjog, mely kitért az egyházi közösségre vonatkozó állami törvények bemutatására (6\%, több mint 100 mű). Előbbi az egyházi bíráskodás kapcsán is komoly jelentőséggel bír, mégis azonban a 19. század második felétől egyre égetőbbé váló vegyesházasságok ${ }^{28}$, vagy állami-polgári házasságkötés miatt bírt komoly aktualitással, melyet a könyvtár állománya is visszatükröz. Az állami egyházjogi munkák közé kerültek besorolásra azon művek is, melyek kifejezetten egy-egy nemzetállamra fókuszálva igyekeztek bemutatni az egyházi jogszabályok rendszerét. ${ }^{29}$ II. József egyházpolitikai döntései szintén bőséges alapul szolgáltak kora kánonjogi kutatásaihoz.

Jelen tanulmány nem vállalkozhat minden egyes jogterület átfogó jellegü bemutatására, így utolsóként az egyházi jogszolgáltatással foglalkozó egységre szeretnék egy pillantást vetni. Az egri Főgyházmegyei Könyvtár kánonjogi állományának egy jelentékeny részét képezi az egyházi bíráskodásra koncentráló szakirodalom. Ennek gyakorlati jelentősége nem is elsősorban a líceumi vagy szemináriumi jogi illetve teológiai képzés során mutatkozhatott meg, sokkal inkább vonhatunk párhuzamot az állomány és a föegyházmegyei szentszék mủködése között.

\section{Összefoglalás}

Az Eszterházy Károly egri püspök által alapított Főegyházmegyei Könyvtár kánonjogi állománya nem csupán a teológiai szakkönyvtár tekintetében, hanem a teljes gyüjtemény fényében is jelentősnek mondható. A négy évszázadot felölelő corpus kutatása során alapvetően igazolást nyert, hogy az egyházjogi állomány összeállítása során az egyetemalapítási szándék mellett szerepet játszott az állomány hasznosulása nem csupán szemináriumi papképzés során, de a szentszéki jogszolgáltatás, bíráskodás esetében is. További kutatásokra tarthat számot annak áttekintése, milyen összefüggések fedezhetők fel más püspöki könyvtárak jogi gyűjteményével. Ha azonban csak a pécsi Klimó György püspök által alapított bibliotéka egyházjogi állományával (360 kánonjogi mủ) hasonlítjuk össze az egri gyűjtemény nagyságát ${ }^{30}$, úgy - az eltérő körülményeket és szempontokat is figyelembe véve - jelentékeny különbségre figyelhetünk fel, hiszen az egri ötszöröse a dél-dunántúli püspöki bibliotéka e szegmensének.

28 Pl. Christoph Friedrich von Ammon: Die gemischten Ehen. Dresden 1839.

29 Pl. Joseph Augustin Ginzel: Handbuch des neuesten in Oesterreich geltenden Kirchenrechtes. Wien 1857.

30 Kiss Gábor: A 19-20. század kánonjogi műveltsége Pécsett. In: Tudomány és kutatás a 240 éves Klimo könyvtárban. Szerk. Dezső Krisztina - Molnár Dávid - Schmelczer-Pohánka Éva. Pécs 2016. 149-162. 
Az egyházjogi kutatás forrását képező törvényszövegek elsősorban párizsi és római kiadásokban kerültek Egerbe. Emellett azonban az Egerben fellelhető kánonjogi bibliográfia leginkább a német nyelvterületek szerzőinek gondolatvilágát tükrözi vissza, hiszen innen származott a legtöbb szisztematikus jellegű monográfia és egyéb tanulmány. További kutatások tárgyát képezheti, hogy vajon az egyházmegye külföldi egyetemet végzett papságának német területeken folyó tanulmányai menynyiben gyakoroltak hatást a könyvtár kánonjogi állományának ilyetén való gyarapodására. ${ }^{31}$

31 Vö. Surányi Imre: Eger fópásztorainak, főpapjainak és felsőfokú tanintézményeinek liber gradualisai az egri Fõegyházmegyei Könyvtárban. In: Emlékkönyv Dr. Seregély István aranymiséje alkalmából. Szerk. Löffler Erzsébet - Seregély György. Eger 2005. 177-227. 


\section{Untersuchung der kirchlichen Bestände der Erzdiözesanbibliothek Eger von der Gründung der Biblio- thek bis 1899}

Im Beitrag wird der kirchenrechtliche Buchbestand der Erzdiözesanbibliothek Eger im Licht von Zeitraum, Ort, Sprache und Thematik der Ausgabe der erwähnten Sammlung geprüft. Anhand der Ergebnissen dieser Forschung der Fachliteratur für Kanonistik ab der Gründung der Bibliothek bis zum 1899 lässt sich sagen, dass die Mehrheit der Rechtquellen aus Frankreich kam, jedoch die monographische, systematische kirchenrechtliche Literatur stammt aus den deutschsprachigen Gebieten. Die kanonistischen Sammlung der geprüften Bibliothek und seine zahlreichen thematischen Einheiten standen zuerst für das rechtliche und theologische Studium und für die Gerichtsbarkeit des Offizialats von Eger zur Verfügung.

\section{Výskum cirkevnoprávneho fondu Arcibiskupskej knižnice v Egeri od jej založenia do roku 1899}

V štúdii sa venujem literatúre kanonického práva nachádzajúcej sa v Arcibiskupskej knižnici v Egeri z hladiska miesta, času vydania ako aj tematiky a jazyka jednotlivých diel. Pre obdobie od založenia knižnice do roku 1899 možno konštatovat', že tu uložené pramene kanonického práva pochádzajú z francúzskeho jazykového teritória. Naopak, väčšina systematizujúcich prác je nemeckého pôvodu. Po vymedzení viacerých tematických celkov je zrejmé, že predmetná cirkevnoprávna zbierka slúžila v prvom rade edukačným účelom. Okrem toho bola využívaná aj z procesného hladiska cirkevného súdnictva. 